\section{International Association of Legal Science}

During mid-September, the Law School was host to the Fifth Annual Conference of the International Association of Legal Science. The Association is composed of a large variety of national organizations which share a common interest in problems of comparative law, jurisprudence, and international law. The 1957 Conference was the first to be held in the United States. Max Rheinstein, Max Pam Professor of Comparative Law, has long taken a prominent part in the work of the Association, and had the leading role in arranging the program of the 1957 Conference. Law School Assistant Dean James Ratcliffe acted as Conference Secretary.

Registration at the Conference was over 120 , with some twenty-two countries represented. The substantive work of the Conference took place in three Roundtables, devoted to a study of The Rule of Law as Understood in the West, The Rule of Law as Understood in Oriental Countries, and The Influence of Law on the Stability of the Family.

In addition to this program, many special events were arranged for the delegates. They visited the jury trial of a civil case, rare in most parts of the world, they were given a tour of the Chicago Title and Trust Company, visited the offices of Kirkland, Fleming,

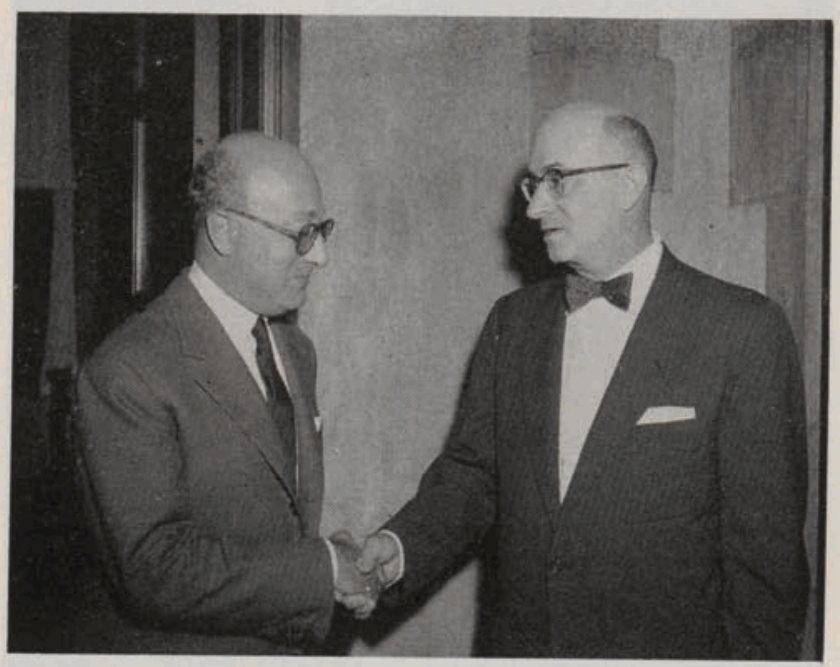

Guiseppino Treves, of Italy, with Joseph Dainow of Louisiana State University.
Green, Martin, and Ellis, and toured the American Bar Center. In addition, delegates were guests of the Law School at a dinner at which Professors Harry Kalven, Jr., and Soia Mentschikoff discussed the School's research in Law and the Behavioural Sciences, and were entertained at a lawn party by $\mathrm{Mr}$. and Mrs. Glen A. Lloyd at their home in Libertyville.

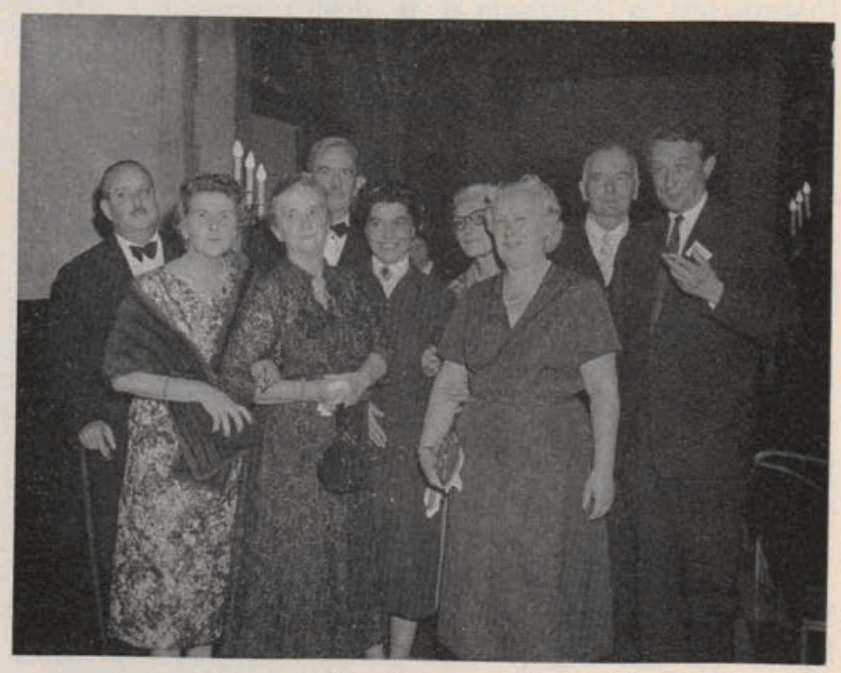

Arriving at the Law School Dinner, left to right, Felipe de Sola Canizares of Spain, Mrs. Hans Ficker, of Germany, Mrs. Hessel Yntema, Hessel Yntema of the University of Michigan, Mrs. Gabriel Marty, of France; Mrs. Max Rheinstein, Mrs. de Sola Canizares, Hans Ficker, and Gabriel Marty.

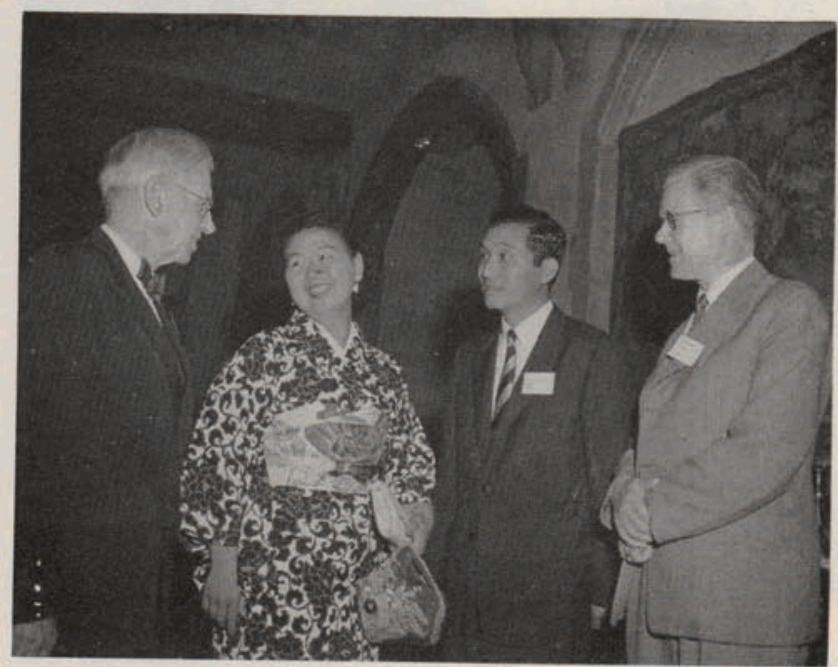

Nils Herlitz, of Sweden, Mr. and Mrs. Shin-ichi Takayanagi, of Japan, and Ake Malmstrom, of Sweden. 